This item was submitted to Loughborough's Research Repository by the author.

Items in Figshare are protected by copyright, with all rights reserved, unless otherwise indicated.

\title{
Building resilience: Knowledge, experience and perceptions among informal construction stakeholders
}

PLEASE CITE THE PUBLISHED VERSION

https://doi.org/10.1016/j.ijdrr.2018.02.039

PUBLISHER

(C) Elsevier

VERSION

AM (Accepted Manuscript)

\section{PUBLISHER STATEMENT}

This work is made available according to the conditions of the Creative Commons Attribution-NonCommercialNoDerivatives 4.0 International (CC BY-NC-ND 4.0) licence. Full details of this licence are available at: https://creativecommons.org/licenses/by-nc-nd/4.0/

\section{LICENCE}

CC BY-NC-ND 4.0

\section{REPOSITORY RECORD}

Chmutina, Ksenia, and Joanne Rose. 2018. "Building Resilience: Knowledge, Experience and Perceptions Among Informal Construction Stakeholders”. Loughborough University. https://hdl.handle.net/2134/32100. 


\title{
BUILDING RESILIENCE: KNOWLEDGE, EXPERIENCE AND PERCEPTIONS AMONG INFORMAL CONSTRUCTION STAKEHOLDERS
}

\begin{abstract}
Nepal is considered one of the most disaster-prone countries is the world, with vulnerabilities exacerbated by chronic poverty. Whilst a variety of sound buildings codes and regulations has been introduced in the past decades, a challenge exists in implementing these as the majority of the building stock is constructed by informal construction workers. Based on a case study of Nepal's Banepa Town, this paper aims to explore the role of knowledge, perceptions of and experiences with disaster risk reduction (DRR) measures among informal construction stakeholders. The paper highlights that whilst the level of awareness of hazards and knowledge of the importance of DRR measures among informal construction stakeholders is high, it is also important to consider perceptions and organisational challenges when finding the best solutions for promoting DRR measures. There is still a gap between transforming knowledge into practice, often because of the perceptions (such as trust, experience, and gender) that are predominant in the sector. Understanding these issues is important as this situation is not unique to Nepal: rapid urbanisation in many developing countries has similarly led to a boom in informal construction sectors and construction that has little regard for building codes and regulations.
\end{abstract}

Key words: disaster risk reduction, informal construction sector, Nepal, built environment

\section{Introduction}

Nepal is located at the border of the Indian and Eurasian tectonic plates and has a complex geophysical structure and widely varying meteorological conditions due to large altitude differences. Such conditions make the country one of the most disaster-prone countries in the world (Gaire et al., 2015). Whilst impacts of earthquakes in Nepal are widely known (particularly since the 2015 Gorkha earthquake (Shresta et al., 2016)), the negative impacts of floods and landslides (mainly caused by intensive rainfall, glacial lake outbursts, soil erosion, snowmelts, deforestation, water leakage, road construction, and infrastructure failure) on livelihoods and infrastructure are also significant (Khanal et al., 2007; Dahal, 2012). The Government of Nepal (2015) also lists fires, epidemics, windstorms, lightning, hailstorms, avalanches, snowstorms, heat and cold waves, and droughts as hazards the country needs to consider.

Disaster Risk Reduction (DRR) efforts are therefore high on the Government of Nepal's agenda. The Government has been working to reduce risks through mainstreaming DRR into sectoral development for preventing the occurrence of disasters, mitigating their impact and ensuring that there is adequate preparedness to ensure an effective response. However, a number of challenges - including poor construction practices - hinder this process (Dixit, 2004). Despite sound building codes and regulations introduced in the early 1990s, more than $98 \%$ of buildings in Nepal are constructed by informally employed local craftspeople. Consequently, most residential buildings are not designed with earthquake resistance in mind. Moreover, although a system of building permits exists in most municipalities, there is no provision for checking the submitted plans against the strength criteria. This applies not only to newly built stock but also to the reconstruction of damaged buildings and the retrofit of existing building stock. Additionally, there is poor institutional and technical capacity within the local authorities for implementing strength-related provisions, even if they were introduced into the building permit process (Dixit, 2004).

Based on a case study of Nepal's Banepa Town and its 11 wards, this paper aims to explore the role of knowledge, perceptions of and experiences with DRR measures in construction process 
among informal construction stakeholders. Understanding these issues is important as this situation is not unique to Nepal: rapid urbanisation in many developing countries has similarly led to a boom in informal construction sectors and construction that has little regard for building codes and regulations.

\section{DRR measures in construction}

It is now widely accepted that construction practise needs to be more sensitive to mitigate the impacts of a wide range of hazards through proactive measures (Bosher and Dainty, 2011; Bosher and Chmutina, 2017). It is important to ensure the built asset is an improved (i.e. more resilient) version of what was originally there, particularly if is repeatedly impacted by the same hazards (Bosher, 2014). There is a myriad of structural and non-structural approaches that help reducing disaster risk, but it is important to acknowledge that structural measures do not fully reduce the risk, ${ }^{1}$ and the implementation of both structural and non-structural measures should be balanced (Bosher and Chmutina, 2017).

\subsection{DRR measures for earthquake resistant construction}

Human settlements can often be found in earthquake prone locations and the impacts of seismic activity are demonstrated throughout the history (such as Antioch (AD115 in modern day Syria), Lydia (AD17 in Turkey) and Crete (AD365 in Greece)). Evidence however suggests that historically people living in seismically active regions had found ways to adapt to the threat of earthquakes (Bosher and Chmutina, 2017). Some of these adaptations have included 'base isolation', vernacular houses using timber framed design with masonry infill walls, traditional houses built using a circular plan design, the use of rocking systems and segmental (multi-block) construction. More novel engineering approaches that improve seismic performance include tuned mass dampers and vibration control measures (Bosher and Chmutina, 2017). Various measures can also be incorporated in different types of construction as presented in Table 1.

Table 1 Summary of most prominent construction types that can incorporate earthquake-engineering features (adapted from Bosher and Chmutina, 2017)

\begin{tabular}{|c|c|}
\hline $\begin{array}{l}\text { Type of } \\
\text { construction }\end{array}$ & Key considerations \\
\hline $\begin{array}{l}\text { Adobe } \\
\text { structures }\end{array}$ & $\begin{array}{ll}\text { - } & \text { Quality of construction; good workmanship and use of natural fibres } \\
& \text { (such as straw to reinforce the clay/brick materials) } \\
\text { - } & \text { Compact, robust layout, single storey with small openings } \\
\text { - } & \text { Seismic features such as buttresses and use of cane for reinforcement }\end{array}$ \\
\hline $\begin{array}{l}\text { Limestone } \\
\text { and sandstone } \\
\text { structures }\end{array}$ & $\begin{array}{l}\text { Application of new technologies (such as base isolators) to seismic } \\
\text { retrofitting }\end{array}$ \\
\hline $\begin{array}{l}\text { Timber frame } \\
\text { structures }\end{array}$ & $\begin{array}{l}\text { - } \quad \text { Skeletal framing which (if properly engineered) lends itself to better } \\
\text { seismic survivability (used in vernacular architecture) }\end{array}$ \\
\hline $\begin{array}{l}\text { Reinforced } \\
\text { masonry } \\
\text { structures }\end{array}$ & $\begin{array}{l}\text { - Reinforcing bars or mesh embedded in the mortar or placed in the holes } \\
\text { and filled with concrete or grout } \\
\text { - A single small entry point and relatively small openings surrounded by } \\
\text { strong wooden elements to compensate for the loss of strength (used in } \\
\text { traditional housing) }\end{array}$ \\
\hline
\end{tabular}

\footnotetext{
${ }^{1}$ Instead of controlling the risk of, for instance flooding, structural DRR measures control the hazard parameters (e.g. the volume of water), which can increase in the future and therefore make structural measures ineffective.
} 


\begin{tabular}{|l|ll|}
\hline $\begin{array}{l}\text { Reinforced } \\
\text { concrete } \\
\text { structures }\end{array}$ & $-\begin{array}{l}\text { Concrete in which rebars or fibres have been incorporated to strengthen a } \\
\text { material that would otherwise be brittle }\end{array}$ \\
& $-\begin{array}{l}\text { Pre-stressed concrete can be applied to beams, floors or bridges with a } \\
\text { longer span than is practical with ordinary reinforced concrete. }\end{array}$ \\
- & $\begin{array}{l}\text { Pre-stressing tendons provide a clamping load which produces a } \\
\text { compressive stress that offsets the tensile stress }\end{array}$ \\
\hline $\begin{array}{l}\text { Pre-stressed } \\
\text { structures }\end{array}$ & $-\begin{array}{l}\text { Pre-compression (mostly, with the own weight of a structure) } \\
\text { - }\end{array}$ & $\begin{array}{l}\text { Pre-tensioning with high-strength embedded tendons } \\
\text { Post-tensioning with high-strength bonded or unbonded tendons }\end{array}$ \\
\hline
\end{tabular}

\section{Overview of Nepal's urban built environment}

There are three broad categories of buildings that are common in Nepal: frame structure buildings; load bearing wall buildings; and earthen building. In reality however most buildings have mixed structural components, and/or different construction materials in different parts and levels (Bothara et al., 2015) (Figure 1). The most popular constructions in the urban areas of Nepal are stone or brick masonry buildings, constituting around $20 \%$ of reinforced concrete (RC) construction (whereas the adobe construction, wooden framed houses and rubble stone masonry constructions are more popular in rural areas). Approximately $80 \%$ of the buildings are do not comply with the existing codes (Gautam et al., 2016), and the construction practices have not improved significantly since the 2015 Gorkha earthquake (Shrestha et al, 2017b). Rapid urbanisation led to a very high rate of building production. Coupled with the absence of proper building permit processes, and a general lack of the knowledge and skills for hazard-resistant construction, this led to the creation of a built environment that is extremely vulnerable to a range of natural hazards, and in particular earthquakes (Dixit, 2004; Gautam, 2016).

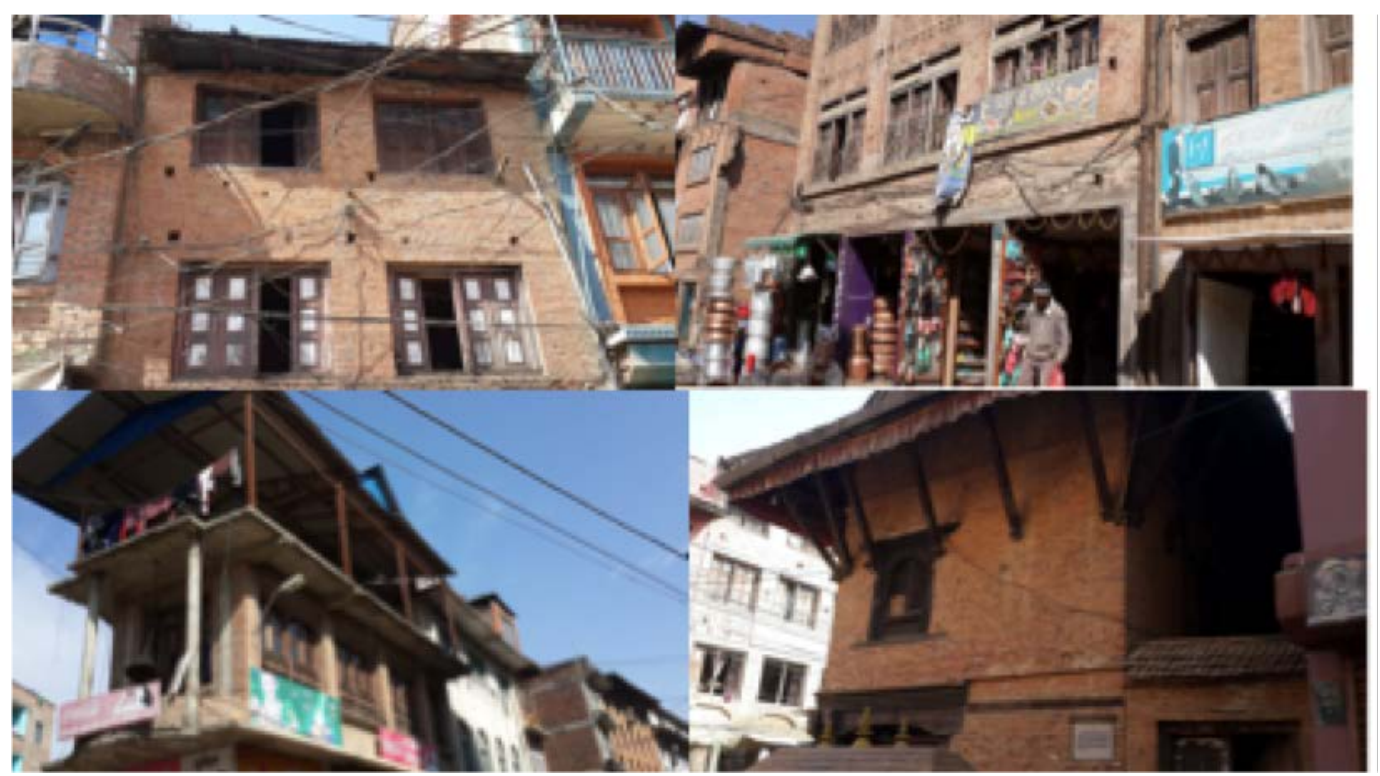

Figure 1 Examples of building types: Load bearing wall building with plank wooden floor and CGI roof; Timber frame on the ground floor and Load bearing brick wall on an upper floor; RCC frame Masonry Infill wall building with Steel Skeleton on the top floor; Partly Load Bearing Wall and Partly timber column (authors’ pictures)

\subsection{Informal construction sector}

The informal sector plays an important role in Nepal's national economy employing about $96 \%$ of the economically active population, and, contributing over $50 \%$ to the national economy (Solomon, 2014). The construction sector is not an exception: only $5 \%$ of individually constructed buildings undergo professional engineering design and supervision (in addition to limited planning control 
and land management). The majority of construction workers employed by registered contractors are engaged through informal contracts (where the responsibility are agreed verbally thus not imposing any liability) (Figure 2). Contractors in the private sector largely depend on unregistered construction enterprises headed by 'Naikeas', the labour gang leaders, who supply labour for their projects. The Naikeas are paid on a piece-rate basis for the sub-contracted portion of the work, or on the basis of a fixed fee (e.g. a percentage of the wage paid to the labourers). The labourers are paid daily wage rates, which do not include any social benefits (such as sick leave or idle period compensations). This informal construction system offers great flexibility in terms of speed of building and lower costs; however, the quality of buildings often suffers (Jha, 2015). In addition, there is a lack of professional accountability, with the client bearing all of the risks and responsibilities. Taking into account the risk profile of the country and the rates of reconstruction and urbanisation, the quality of construction work is a salient issue (Jha, 2015).

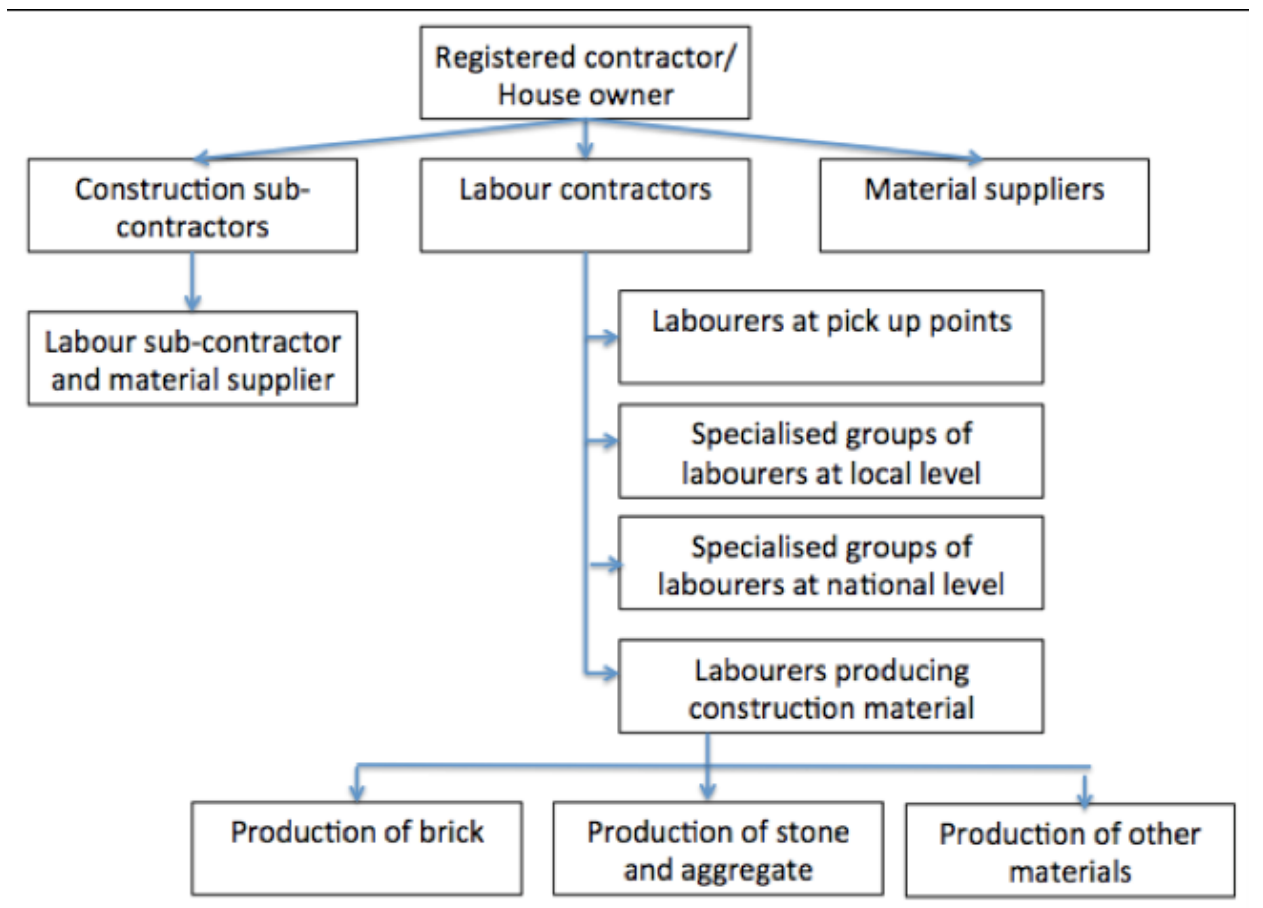

Figure 2 Organisational hierarchy of informal construction stakeholders in Nepal (adapted from Jha, 2015)

For the majority of construction workers, the construction sector is an additional income to their agricultural activities. The construction teams can be joined either through relatives and friends already working under a Naikea, or at the pickup points (places known locally, where workers gather in the hope of recruitment for the day or a project with a Naikea). Workers start as unskilled labourers and acquire their skills through on the job training. After several years in the industry, most male workers progress to the semi-skilled or skilled categories, or establish their own enterprises. Whilst more women are doing construction work that was previously seen as 'work of men' (Ampilan, 2016), there are still few career progression opportunities for female workers, and women are largely involved in in the low skill professions (for instance, stone crushers) (Jha, 2002; Sigmund, 2011).

\subsection{Nepal's Building regulations}

The Nepal National Building Code (the Code) was formulated and implemented in 1993 by the Department of Urban Development and Building Construction, following the lessons learned from the 1988 earthquake, which killed more than 700 people. The Code was approved by the Government in 2003 and is a legally binding document in all 130 municipalities. It is however not applied to towns and villages (which fall under village development committees (VDCs)), although 
some VDCs around Kathmandu have voluntarily adopted the Code. The Building Act, Building Regulations and the Building Code outline the building construction legal obligations to be followed by the builders or clients through the local government. The Code establishes a permit system, peer review, monitoring, certification of construction practices, and implementation of land use planning measures, but allows the use of any international codes and standards that meet its minimum requirements.

It is important to emphasise that unlike many other building regulations, the Code notes the importance of locally available building materials or prevalent forms of vernacular construction, such as adobe and non-engineered ${ }^{2}$ construction, and allows the full range of locally prevalent construction types, including non-engineered indigenous structures. It also acknowledges the dominant role of informal construction groups that do not have professional construction training, and sets realistic objectives for the design of technical standards and guidance materials and proposes technical guidance known as "rules of thumb," assuming that simple but essential structural details could be checked by non-specialist staff of municipal building departments (World Bank, 2015).

Despite having sound building regulations, the implementation of the Code remains an issue. Challenges related to the lack of capacity for monitoring of implementation have been hindering the impacts of the Code since it was first legally enforced. It is the responsibility of municipalities to issue building permits, however current municipal building permit approval processes do not ensure the compliance with the Code. Few generic checklists have been developed but these are often overlooked and easily manipulated, and there is no effective mechanism to verify that building drawings approved by the municipality are actually reflected in an actual projectuction project (Shrestha et al., 2017b). Compliance enforcement is further challenged by the high workload and limited number of trained professionals (Giri, 2015): in some municipalities approximately 4,300 houses are constructed annually but there is only one engineer and one assistant engineer to look at the whole process (Shrestha et al., 2017a). In addition, there is a low level of awareness of the Code among the informal construction stakeholders.

\section{Methodology}

The research was designed as a single qualitative case study of Banepa Town, employing both primary and secondary data collection. The data were collected by Nepali researchers, under the supervision of the authors. This approach addressed a number of common limitations, such as removing the language barrier, unwillingness to speak to a foreigner, deep understanding of the different cultures and castes, as well as access to different groups of workers. In order to understand the informal construction stakeholders' awareness of DRR measures, a case study approach (most appropriate when questions whether and how are asked) (Yin, 1994; Eisenhardt, 1989) was undertaken using the following steps.

Firstly, a scoping review was conducted to identify existing research and secondary data (including NGO reports, grey literature and research publications). Site visits to the wards of Banepa Town and data collection were conducted in April-May 2017, which helped to obtain a valuable insight (Lofland and Lofland, 2011) when discussing on-going development projects and to understand the environment and the context in which the projects are taking place.

\footnotetext{
${ }^{2}$ Non-engineered construction can be defined as buildings that are 'spontaneously and informally constructed [...] in the traditional manner without any or little intervention by qualified architects and engineers in their design’ (Arya, 2000, p.1)
} 
Banepa is located in the Kabhreoalanchok district, approximately $25 \mathrm{~km}$ east from Kathmandu. A vast number of buildings were damaged and destroyed in the 2015 Gorkha earthquake, and the rate of construction work (which is governed by VDC) in the area is therefore high (Figure 3).

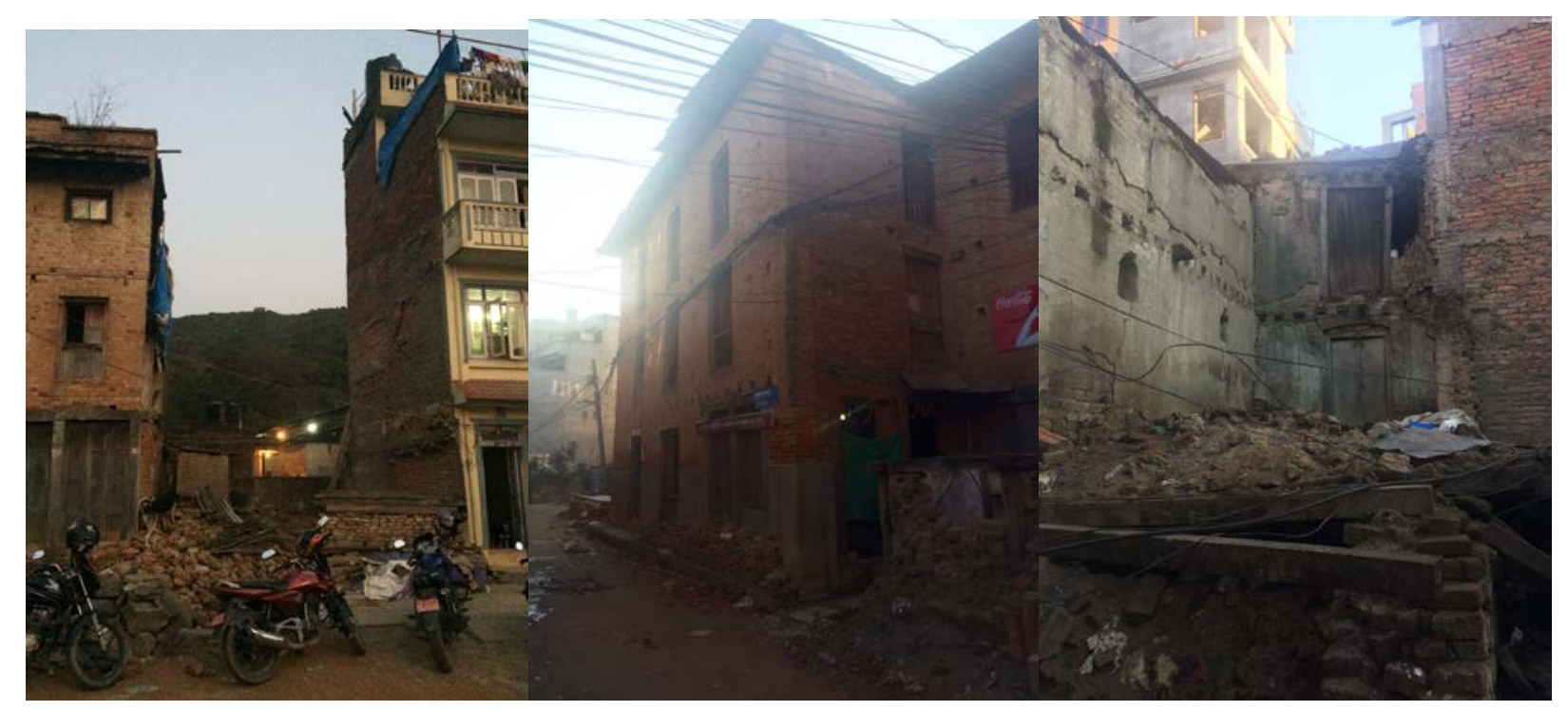

Figure 3 Images of Banepa's damaged building stock (authors’ pictures)

Secondly, two Naikea groups from each of the 11 wards in Banepa were contacted. The following criteria for the selection of Naikea groups had to be met: to be operational for over 10 years; currently active; and comprise the full spectrum of informal construction workers. Following this, two groups were selected at random. All members (from brick carrier to team leader) of each Naikea group were invited for interview, however not all were able to participate as a result of time and work commitments; or they preferred not to participate. Despite this, the 92 interviews were conducted with the full spectrum of workers (both male and female) representing age groups operating in the sector (Table 2). Each interview was approximately 60 minutes in duration, covering the following aspects: main hazards, workers' awareness of and engagement in DRR, and overall willingness to implement DRR measures in their practice. The interviews were recorded and thematically analysed. Thematic analysis was chosen due to the complexity of the dataset and the need for a flexible analytical process to provide a structure (Howitt and Cramer, 2011).

Table 2: Overview of interviewees' demographics

\begin{tabular}{|c|c|c|c|c|c|}
\hline & & Contractors & Clients & $\begin{array}{l}\text { Skilled Labour } \\
\text { (masons, } \\
\text { carpenters) }\end{array}$ & $\begin{array}{l}\text { Unskilled } \\
\text { labour (stone } \\
\text { carriers, } \\
\text { cement mixers) }\end{array}$ \\
\hline \multicolumn{2}{|c|}{ Total number of interviews } & 24 & 16 & 30 & 22 \\
\hline \multirow{2}{*}{ Gender } & Male & 24 & 15 & 30 & 9 \\
\hline & Female & - & 1 & - & 13 \\
\hline \multirow{3}{*}{ Age } & $15-24$ & 24 & 2 & 4 & 4 \\
\hline & $24-58$ & - & 13 & 25 & 16 \\
\hline & $58+$ & - & 1 & 1 & 2 \\
\hline & $\begin{array}{l}\text { No formal } \\
\text { education }\end{array}$ & 7 & 2 & 18 & 12 \\
\hline & $\begin{array}{c}\text { Basic } \\
\text { education }\end{array}$ & 11 & 1 & 7 & 3 \\
\hline
\end{tabular}




\begin{tabular}{|c|c|c|c|c|c|}
\hline $\begin{array}{c}\text { Education } \\
\text { level }\end{array}$ & $\begin{array}{c}\text { Secondary } \\
\text { education }\end{array}$ & 6 & 8 & 5 & 1 \\
\cline { 2 - 5 } & $\begin{array}{c}\text { Higher } \\
\text { education }\end{array}$ & - & 5 & - & - \\
\hline
\end{tabular}

Thirdly, two focus groups with a combined total of 24 participants (12 male and 12 female informal construction workers) representing a full range of Naikea levels (from female unskilled workers to contractors) was drawn upon to access a deeper individual understanding, framing and operationalisation of natural hazards and disaster risk reduction measures. The 50/50 gender division was not representative of the construction workforce; however it allowed representing female opinion, which was critical for the project, as the roles played by men and women in construction differ (as has been explained in previous sections). Focus groups allowed the authors to capture a range of shared narratives, alongside features of Naikea cultures, as participants built on the insights of peers from common communities of practice (Bryman, 2012). In order to provide a more comfortable environment that accounts for the cultural and educational background of the participants, the focus groups were partially conducted in a form of a dice game aimed at exploring risk perception and decision making process of informal construction stakeholders. During the game, participants were divided into two groups: the first group included more skilled younger workers, and the second groups included older but less skilled workers. ${ }^{3}$ Such division was deliberate: the facilitators felt that the less skilled workers would not be willing to freely express their opinion in front of their more senior (in terms of skills and Naikea standing) colleagues.

\section{The role of information construction stakeholders in delivering resilient built environment in Nepal}

As already demonstrated in Chmutina et al. (2018), a number of challenges (including poor quality of construction materials, lack of financial resources, issues related to availability of access to training) disincentivise the incorporation of DRR measures in construction process. However, some prominent perceptions and organisational challenges, which hinder the sharing of knowledge and implementation of good practice, also need addressing.

\subsection{Knowledge of DRR measures among informal construction workers}

The majority ( $n=57$ ) of interviewees demonstrated some knowledge of structural DRR measures in construction process, as well as awareness of the existence of the Building Code (Figure 4).

\footnotetext{
${ }^{3}$ In the context of informal construction in Nepal, 'skill' does not equate to the level of education received; instead it directly relates to a type of construction job performed and the type of skilled required. A person who joins a construction group is treated as unskilled; through acquiring specific skills (e.g. masonry) a progression to a skilled worker status taken place overtime (Jha, 2015).
} 


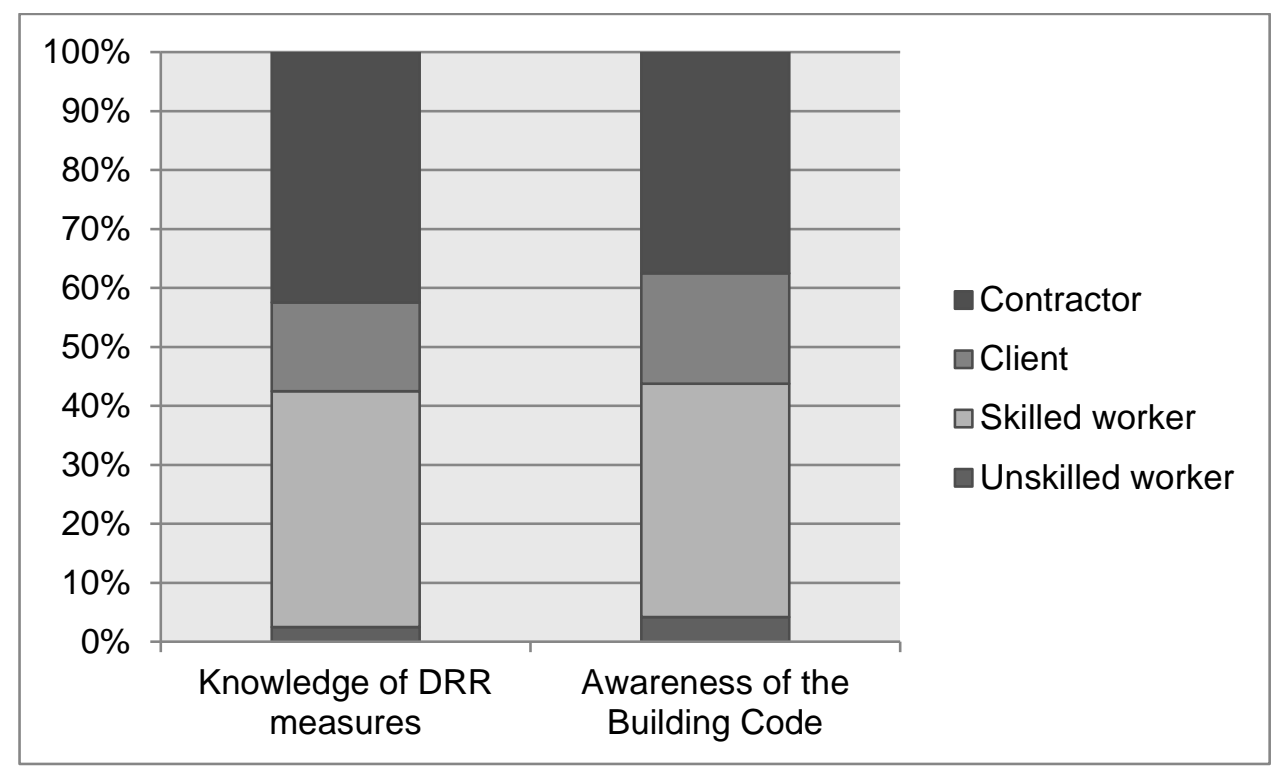

Figure 4 Number of interviewees referring to the Code and bylaws for information during the construction process

Many of the interviewees ( $n=46)$ and focus group participants acknowledged the benefit of engaging with experts (i.e. qualified engineers) and highly skilled and well-trained contractors. Advice from experts is considered to be the best way of getting the knowledge (Figure 5).

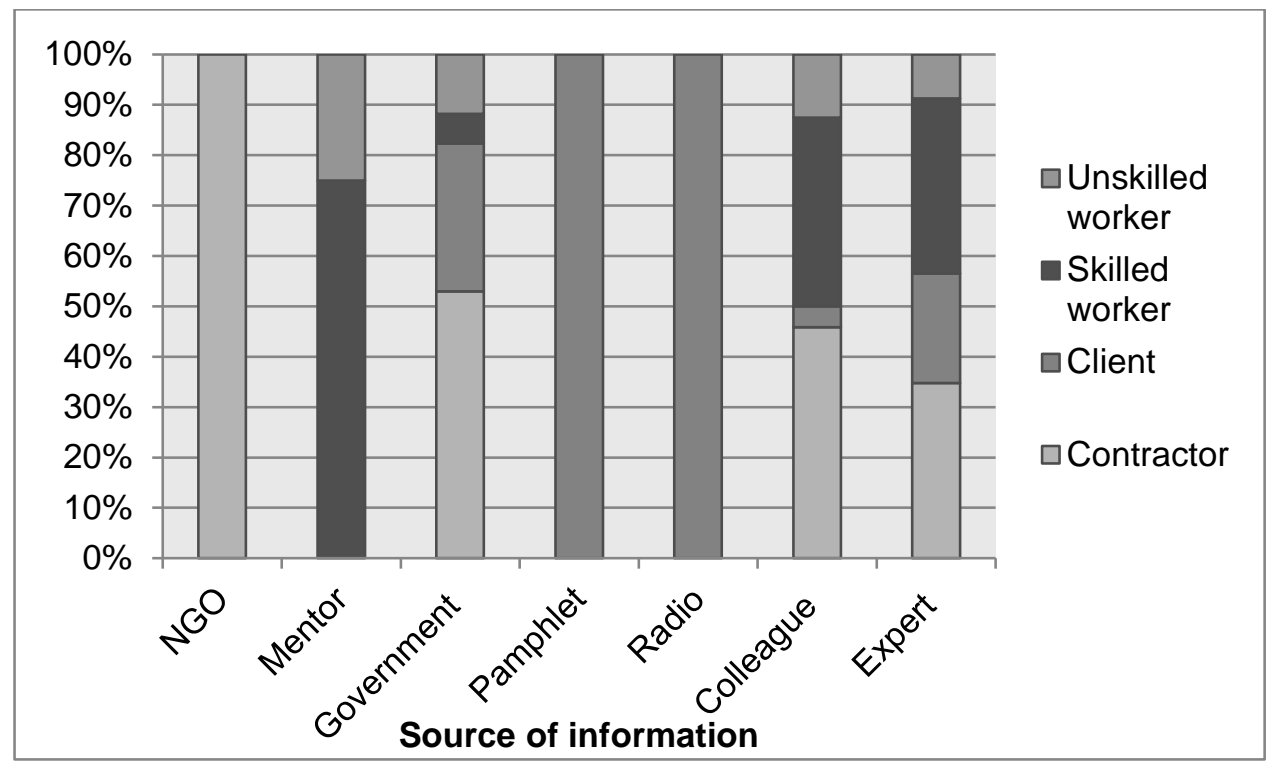

Figure 5 Most trusted sources of information (based on interview responses)

Training also proved to be an important source of knowledge. Existing training initiatives range in scale and level. For instance, the Department of Urban Development and Building Construction led a series of capacity building and trainings on earthquake resistant construction for almost 9,000 masons. The National Society for Earthquake Technology (NSET) has undertaken a series of initiatives, including Shaker Table demonstrations; technical training for engineers and subengineers; training of trainers; and support to 30 municipalities to improve building permit processes and implementation of the building codes. Training however is largely aimed at contractors and skilled workers (19 out of 24 contractors and 8 out of 30 skilled workers interviewed were trained, as opposed to 2 out of 22 unskilled workers) and mainly focuses on earthquake resistant construction, and knowledge is then largely shared 'on the job' (as pointed out by both focus groups and 54 interviewees). 
The education level of a contractor also played an important role. A contractor is the main point of communication between and with clients, experts and workers, thus the level of education affects the understanding of what is required and the way the information is passed to all interested parties. If the contractor lacks technical knowledge, they will not be able to pass technical information from an expert (e.g. engineer) to the construction team. Nevertheless, in order to progress professionally (e.g. become a Naikea lead) education level is irrelevant; the main consideration is experience (as discussed later in this section).

\subsection{Perceptions towards hazards and DRR measures among informal construction workers}

It is important to understand the perceptions towards integrating DRR measures in the building process as well as understanding of disaster risk. Informal construction workers share some attitudes based on their experiences and knowledge (or a lack of these), all of which have an impact on construction process.

All interviewees and focus groups' participants demonstrated that the awareness of hazards is high among the informal construction stakeholders. From the most prominent hazards that should be considered during the construction process, participants acknowledged earthquakes, floods, storms, fire, lightning, and landslides (in order of importance). The 2015 Gorkha earthquake acted as a driver for many stakeholders, from clients and informal construction workers to INGOs and the Government, to rethink how buildings are constructed in Nepal and to drive towards more resilient buildings.

Conversely however, the 2015 Gorkha earthquake has resulted in a single hazard planning approach. This is not surprising as its severe impact is still prominent. Flooding was also occasionally referred to by some participants, but largely as an afterthought. Whilst floods affect many of Nepal's urban areas, the impacts are not as widely spread and therefore noticeable. A few participants also referred to cascading effects of some hazards (e.g. a causal relationship between a flood and a landslide), however this is not taken into account in a construction project. Instead, a 'knee-jerk' reaction became obvious in the focus groups, in particularly with the older group: for example, in the game, they chose to invest in measures to address hazards that 'affected' them in previous rounds of the game (with their choice of earthquake proofing in the first round of the game).

Related to hazards are the attitudes towards prevention and response. Though the majority of the focus group participants shared a belief that, whilst the impacts of earthquake should be considered pre-emptively and the protective measures should be built-in, the impacts of other hazards cannot be mitigated and the focus should be on response. This was particularly prominent for flood and fire: when the latter came up during the focus group game, the participants agreed that fire prevention cannot be incorporated into construction process. In reality however, the Government of Nepal introduced the Fire Safety Code of Nepal (NNBC 107) in 1994. What may be reflected by the focus group is the fact that the Code is only limited to provisional recommendation on Fire Safety and covers ordinary buildings, and has not been integrated into the Building Bylaws governing the Building Permit procedures (The Government of Nepal, 2009). Such perception highlights that the information construction stakeholders do not necessarily engage with the government level regulations and enforcement on the ground is needed.

The attitude towards the ownership of risk creation was also discussed: due to the organisational hierarchy of Naikea, there is very little understanding of the impact of each worker's role on an overall project: "I carry bricks, gravels and sometime cements on construction site. We are assigned to do those works and we don't interfere in other work" [Interview with an unskilled male worker]. Moreover, all communication occurs through and by a contractor; there is no direct link of communication between a client and an engineer, or an engineer and a skilled worker. This may 
not only result in an incorrect message (as was discussed earlier in relation to the contractor's level of education) but also leads to the lack of appreciation and non-monetary reward: if the project is delivered successfully, the 'glory' is going to the contractor (who thus gets more work since he is gaining more experience - and trust - in delivering the projects), whereas if the project fails the workers (as a whole group) are blamed.

The attitude of and towards the clients is also not always positive: contractors do not feel that the clients want to spend more money (i.e. their aim is to achieve their building as quickly and cheaply as possible), because, according to contractors, clients do not understand the relationship between the impacts of hazards and the construction practice in reducing disaster risks. In their research, Shrestha et al. (2017a) draw on a good practice introduced in one of the municipalities, where clients are now required to be involved in all steps of obtaining a building permit and thus cannot blame lack of knowledge in case of non-compliance (Shrestha, 2011). This increases clients' willingness to pay additional amounts to make their houses earthquake resistant (Shrestha et al., 2017b). Similar rules, if implemented in Banepa, may also help address this issue.

This affects the relationships between clients and contractors: both parties feel that the lack of trust between the clients and contractors (clients claim that some contractors do not listen to them, whereas contractors argue that clients do not understand the construction process and thus must trust the contractors) hinders the resilience of the project.

\subsection{Experience of DRR measures among information construction workers}

Throughout the interviews and focus group discussions, experience was often referred to as an important aspect of ensuring resilience building (Figure 6); learning on the job is the main way of receiving knowledge and experience, as the access to training is somewhat limited but in order to enhance their experience most of the interviewees noted that they apply information about DRR measures in their daily working practice and share it with others (Figure 7)

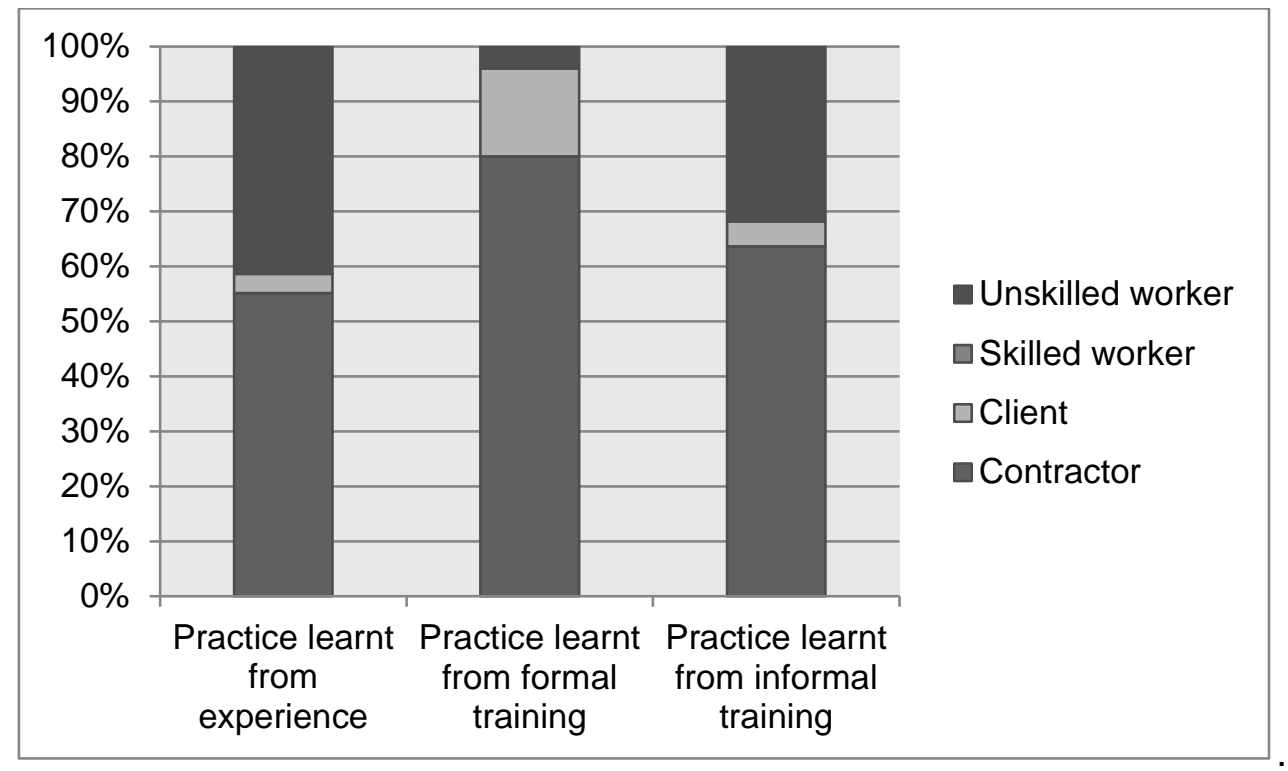

Figure 6 Overview of learning preferences (based on the interview responses) 


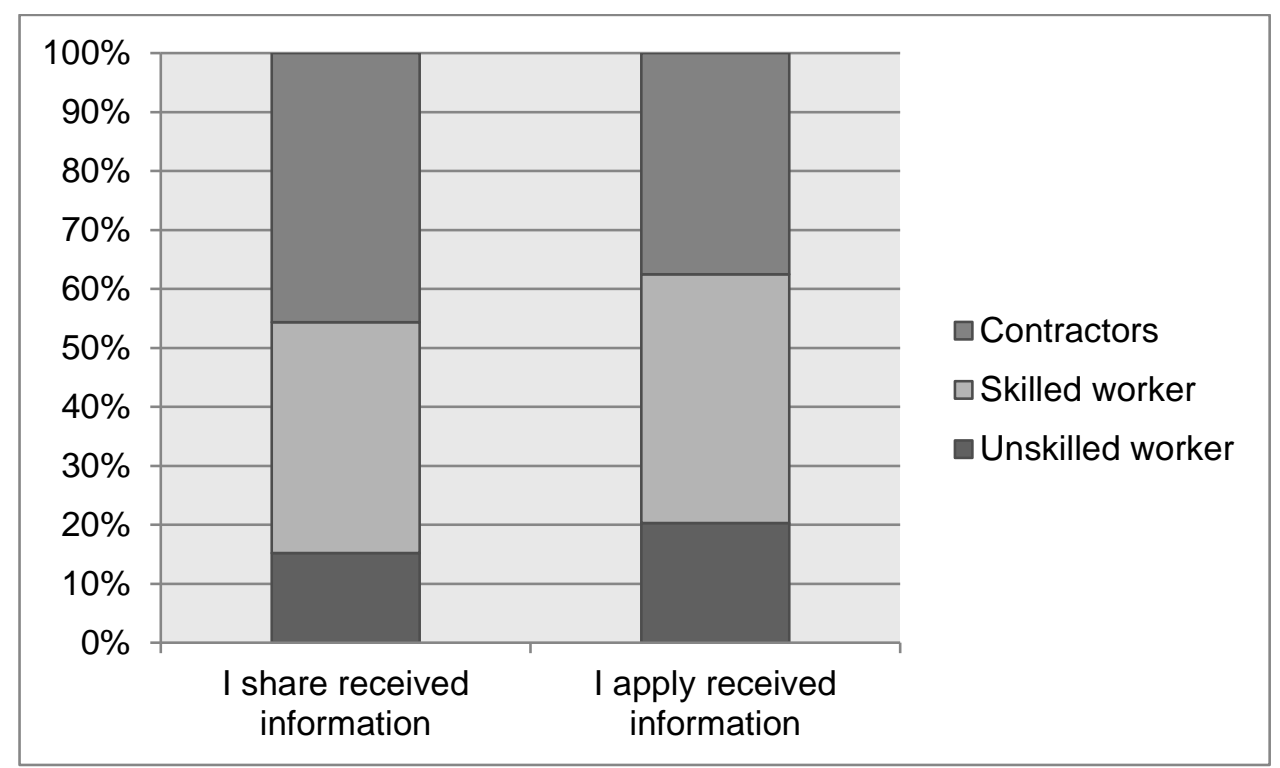

Figure 7 Interviewees responses regarding the rate of application and sharing of their DRR knowledge

The experienced (in this context, more skilled rather than older) workers had a clear understanding that incorporation of DRR measures into building techniques is important from the start of the project; for instance, much of the discussion in the interviews and during the focus groups centred on the strength of foundations as it helps withstanding earthquakes. The construction experience is seen as a particularly important asset among the skilled workers who are targeted by a variety of training opportunities (mainly for the earthquake proofing techniques). The choice of enhancing the skills of those most skilled may seem strange; however the Naikea members traditionally disseminate knowledge on site (as already discussed). Focus group participant explained that 'it is easier for them [skilled labour] to grasp new ideas'.

In addition, some of the focus group participants noted that experience often equals reputation of the worker and the team s/he are working in (as many teams are employed through word of mouth), helping developing trust between a client and a Naikea. Yet trust does not always lead to good construction practices: clients tend to choose builders they know (i.e. they can trust), who usually are older builders. Since many of the most 'trusted' ones are extremely busy with the reconstruction after the earthquake, they do not have time to be trained, whilst younger workers (who may have also received training) are often unemployed because their reputations have not been established yet. Moreover, even if skilled workers with good reputations get trained, they often go abroad seeking higher income. Women could be good candidates for receiving training (as they do not tend to go abroad for work), however the construction experience does not count when it comes to gender issues: female workers only tend to do unskilled work (e.g. brick carrying). 'If I know how to do technical works, why is it that being a female puts me in a position only suitable to carry out menial works?' [focus group participant]. This was reflected in the focus group dynamics: a female worker noted that more fire preventive measures should be built-in, however her male counterparts argued that 'no matter how we built the house, the impact of fire is [...] unavoidable'.

Experience is also seen as a source of knowledge, however as discussed in the previous section, it is not clear whether sharing experience is always a good idea. In particular, this is an issue when older workers, who are seen as the ones who know what they are doing, may not actually have appropriate skills and therefore they may be passing the wrong information. Lack of willingness to learn and accept that disasters can be prevented among the older generation of workers was also noted in the interviews: "It's been many year I have been working as labour in this field. Now I have no interest in participating in any training related to construction" [interview with an unskilled male 
worker, age 44]. The second focus group (older, less skilled) shared a belief that 'knowledge and training will not be helpful if they [the participants] have that extent [high intensity] of a [disaster]'.

\section{Conclusions}

This paper demonstrated that whilst the level of awareness of hazards and knowledge of the importance of DRR measures among informal construction stakeholders is high, some of perceptions and organisational challenges are also important to consider when finding the best solutions for promoting DRR measures. The interviews and focus groups (as well as previous research done in this area) indicate that most of the informal construction workers across all levels appreciate and are willing to be involved in training. It is also apparent they want this training to be delivered by experts or engineers in the field. However there is still a gap between transforming knowledge into practice, often because of the perceptions that are predominant in the sector.

Gaining knowledge is problematic. Whilst a large number of successful initiatives aimed at enhancing the skills of the informal construction stakeholders are taking place, many of these are focused on specific groups of workers and specific types of hazards. The overall perception among the workers is that only already skilled workers can receive more training, whereas those with less skills/ lower levels of responsibility do not have access to training. On the job training is a popular method of gaining knowledge among the informal construction stakeholders, however in reality it may not be such a good idea as it is not clear what exactly they learn and to what extent it is applied; in addition, it is not clear how exactly such knowledge is shared. It is also acknowledged that some socio-demographic factors such as increasing age, lower education level, previous experience of earthquake, non-participation in awareness/training program are enhancing lack of DRR awareness (Shresta et al., 2017a).

The question about the effectiveness of the 'on the job' training also remains: the training is focusing on specific elements, and whilst the workers are learning, there is a limit to how much they can learn. The trainees cannot learn how to build a whole building as a training programme simply as it cannot last that long; instead all their knowledge comes from building just one wall. It is therefore not clear whether such training is effective on site.

Relationship issues - despite the hierarchical nature of the informal construction groups, which are highly reliant on experience and trust - hinder incorporation of best practice. A change in attitude towards younger less experienced, as well as female workers is needed for the construction sector to be sustainable in a social and economic sense; otherwise the delivery of a resilient built environment will remain challenging.

There is an appreciation among the informal stakeholders of a need to move towards a multihazard approach taking into account that certain DRR measures, whilst effective for one hazard, can create more damage in the case of another (for instance timber structure may perform well in an earthquake but are highly prone to fires). At the same time, living memory is both a driver and a barrier: whilst the memory of 2015 earthquake acts as a 'wake up' call and encourages informal construction stakeholders to implement earthquake proof measures, the mitigating measures aimed at other hazards are largely neglected.

The informal construction sector alone however, cannot be blamed for creating the risks. Urban planning and strict implementation of land use policies and building codes have a large role to play to discourage clients investing in buildings located in risk-prone areas. There is a need for a more integrated, top-down and bottom-up approach to incorporate DRR in building practices, which should include not only training on structural measures but also awareness of clients and an increase in engineering capacity. Addressing these challenges is becoming more and more critical if we hope to achieve sustainable, disaster resilient urban areas. Nepal does not stand alone in this situation. By 2050 over 66 percent of the world's population is projected to be urban, and Asia is 
urbanising faster than any other region in the world (United Nations, 2014). Similar to Nepal, much of the urbanisation in Asia is occurring with little regard to building standards (Collier and Venables, 2017). Consequently, sustainable development challenges are becoming concentrated in urban areas. Ultimately, how Asia develops its built environment is critical. Poorly planned and constructed developments will seriously restrict any social and economic development. It is pivotal, in countries such as Nepal, that all stakeholders are positively engaged to develop a sustainable and resilient built environment.

\section{Acknowledgements}

This research is undertaken as a part of the Royal Academy of Engineering's Global Frontiers for Development Seed funding.

\section{References}

1. Ampilan, A., 2016. Women in a men's world. 29 April. Available at: https://nepal.oxfam.org/blog/women-men's-world (accessed 9 February 2018).

2. Arya, A.S., 2000. Non-engineered construction in developing countries -an approach toward earthquake risk prediction. In: Proceedings of 12 WCEE, paper 2824. Available at: http://www.iitk.ac.in/nicee/wcee/article/2824.pdf (accessed 8 February 2018).

3. Bosher L.S., 2014. Built-in resilience' through Disaster Risk Reduction: Operational issues, Building Research \& Information, 42 (2), 240-254.

4. Bosher, L. and Chmutina, K., 2017. Disaster risk reduction for the built environment: An introduction. UK: Wiley-Blackwell.

5. Bosher L.S. and Dainty A.R.J., 2011. Disaster risk reduction and 'built-in' resilience: Towards overarching principles for construction practice, Disasters, 35 (1), 1-18

6. Bothara, J.K., Dhakal. R.P., Ingham, J.M. and Dizhor, D., 2016. The Challenges of Housing Reconstruction after the April 2015 Gorkha, Nepal Earthquake. Gorkha Earthquake Special. Nepal Engineer's Association, 121-134.

7. Bryman, A., 2012. Social Research Methods. 4th ed. Oxford.

8. Chmutina, K., Rose, J., Shrestha, S.D. and Bhatta, D.2018. Pathways to raising disaster risk reduction awareness among the informal construction stakeholders: a case of Nepal. In: The Proceedings of $7^{\text {th }}$ Building Resilience Conference, 27-29 ${ }^{\text {th }}$ Nov. 2017, Bangkok, Thailand, Procedia Engineering, 212, 784-791.

9. Collier, P. and Venables, A.J., 2017. Urbanisation in developing economies: an assessment. Oxford Review of Economic Policy, 33, (3), 355-372.

10. Dahal, R.K., 2012. Rainfall-induced landslides in Nepal. International Journal of Erosion Control Engineering, 5, 1-8.

11. Dixit, A.M., 2004. Promoting safer building construction in Nepal. In: Proceedings for 13th World Conference on Earthquake Engineering, Vancouver, B.C., Canada, August 1-6.

12. Eisenhardt, K.M., 1989. Building theories from case study research. The Academy of Management Review, 14, 532-50.

13. Gaire, S., Delgado, R.C., and Gonzales, P.S., 2015. Disaster risk pro le and existing legal framework of Nepal: floods and landslides. Risk Management and Healthcare Policy, 8, 139-149.

14. Gautam, D., Rodrigues, H., Bhetwal, K.K., Neupane, P. and Sanada, Y., 2016. Common structural and construction deficiencies of Nepalese buildings. Innovative Infrastructure Solutions, 1, 1-18. Giri, N., 2015. Implementation of Nepal National Building Code Through Automated Building Permit System. Available at: http://www.preventionweb.net/publications/view/35258 (accessed 21 October 2017). 
15. Howitt, D. and Cramer, D., 2011. Introduction to Research Methods. Prentice Hall, UK, 2011.

16. Jha, K.K., 2002. Informal labour in the construction industry in Nepal. International Labour Organization, Sectoral Activities Programme, Working Paper 187.

17. Jha, K.K., 2015. Presentation on construction sector in Nepal. Nepal Engineers' Association, NSET.

18. Khanal, N.R., Shrestha, M. and Ghimire, M., 2007. Preparing for Flood Disaster: Mapping and Assessing Hazard in the Ratu Watershed, Nepal. ICIMOD and UNESCO.

19. Shrestha, S., 2011. Experience of bulding code implementation in Dharan Municipality. Voice of Cities, 11 (3), 105-20.

20. Shresta, A.B., Bajracharya, S.R., Kargel, J.S. and Khanal, N.R., 2016. The impact of Nepal's 2015 Gorkha earthquake-induced geohazards. Available at: http://www.preventionweb.net/publications/view/48824 (accessed 21 October 2017).

21. Shrestha, N., Dixit, A.M., Shrestha, S.N. and Pradhan, S., 2017a. Changing risk perception of people: a key for enhancing building code compliance. In: Proceedings of the $16^{\text {th }}$ World Conference on Earthquake, Santiago, Chile, 9-13 January, paper 1862.

22. Shrestha, S., Mul, R.L., Lama, S.P., Bhatta, D.R. and Pradhan, S., 2017b. Improving building permit system for building code enforcement: applicable for medium sized municipalities. In: Proceedings of the $16^{\text {th }}$ World Conference on Earthquake, Santiago, Chile, 9-13 January, paper 2315.

23. Sigmund, F. 2011. Nepal's informal economy. AWO International [online]. Available at: http://www.awo-

southasia.org/fileadmin/websites/nepal/South_Asia_pdf/Nepal_s_Informal_Economy.pdf (accessed 8 February 2018).

24. Solomon, O.H. and Shrestha, S., 2014. Does the Informal Sector Thrive Under Democracy or Autocracy?: The Case of Nepal. The Journal of Developing Areas, 48, 245-67.

25. The Government of Nepal, 2009. Recommendation for Update of Nepal National Building Code. Final Report. Ministry of Physical Planning and Works Earthquake Risk Reduction and Recovery Preparedness Programme for Nepal (UNDP/ERRRP-Project: NEP/07/010)

26. The Government of Nepal, 2015. Nepal Disaster Report 2015. Availbale at: http://www.drrportal.gov.np/uploads/document/329.pdf (accessed 21 October 2017)

27. World Bank, Building regulation for resilience: Managing Risks for Safer Cities. 2015. 28. Yin, R.K., 1994. Case study research: design and methods, Sage Thousand Oaks, UK. 